\title{
TRANSPORT PARAMETERS OF POTASSIUM FROM DIFFERENT SOURCES IN SOIL COLUMNS
}

\author{
Nathane M. S. Vilela ${ }^{1}$, Michael S. Thebaldi' ${ }^{*}$, Bruno De P. Leal ${ }^{3}$, Ascânio V. Silva ${ }^{3}$, \\ Ivani P. Martins ${ }^{3}$
}

${ }^{2 *}$ Corresponding author. Centro Universitário de Formiga/ Formiga - MG, Brasil. E-mail: msthebaldi@uniformg.edu.br

\section{KEYWORDS}

breakthrough curves, environmental contamination, miscible displacement

\begin{abstract}
This study aimed to determine some transport parameters of potassium in soil columns by miscible displacement of effluent from a Sewage Treatment Plant (STP). This effluent was collected at different stages of treatment, and potassium chloride solutions were prepared with the same K pulse concentration as the effluent. They were used to conduct a miscible displacement experiment of potassium in soil columns of dystrophic Red Latosol. Both types of solutions contained concentrations of 30 and $32 \mathrm{mg} \mathrm{L}^{-1}$ of potassium. STANMOD software was used to obtain the retardation factor (R) and the Peclet number $(\mathrm{Pe})$ from pore volume and relative concentration. Both retardation factor and solid-water partition coefficient of the soil showed significant results by ANOVA. When assessing $\mathrm{KCl}$ solutions, retardation factor was higher than that observed for the effluent, resulting in higher soil-solute interaction. The presence of other competitor cations in the effluent caused less potassium adsorption by the soil. Based on the results, potassium provided a greater groundwater pollutant potential when applied via effluent than solutions of potassium chloride with the same ion concentrations.
\end{abstract}

\section{INTRODUCTION}

Fertilizer application via irrigation water, termed as fertigation, has been widely used in agriculture, mainly in fruit and vegetable production (Pereira et al., 2016). Soluble fertilizers may have a prominent role in this system since their concentrations and application frequencies can be easily managed, following crop demands, and its use systematized according to the irrigation system infrastructure. Therefore, urea, potassium chloride, and single superphosphate have been valued formulations (Hoshino et al., 2016).

In this context, Santos et al. (2016) evaluated the effects of potassium chloride via irrigation on dripper emission rates and soil chemical properties $(\mathrm{pH}$ and electrical conductivity) in papaya trees (Sunrise solo cultivar). According to these authors, fertilizations reached a horizontal distance of $0.40 \mathrm{~m}$ from the dripper and in depth and caused no clogging of emitters during the studied period, in addition to not reducing soil $\mathrm{pH}$ or salinity levels. Nonetheless, Mendes et al. (2016) concluded that the $\mathrm{K}$ leaching increases as the irrigation depths are increased, reducing in 7.99 and $57.04 \%$ the amount applied to clayey and sandy soils, respectively.
Therefore, given the above-mentioned results and despite the obvious benefits brought to intensive and automated agriculture, responsible for sustaining the global food supply, these processes cause many problems, mainly to environmental and water resources. The chemical contamination of soil and water may cause human and animal health risks and jeopardize new cropping areas (Jadoski et al., 2010), especially in situations where irrigation and fertigation are performed without minimal criteria for sustainability.

The agricultural use of sewage presents itself as a sustainable way of water resource consumption, which can be directly destined to population or even animals. Costa et al. (2012) affirmed that effluent use could be considered a social, economic, and environmentally sustainable alternative to fertigations given the large amount of nutrients similar to nutritive solutions. Furthermore, poorly managed irrigations could lead to deep percolation and leaching, which transport solutes, such as pesticides and other chemical elements, to the subsurface soil layers of agricultural areas (Gonçalves et al., 2016).

Water dislocation breadth and further groundwater contamination by ions and other dissolved elements can be characterized by studies on miscible displacement, which

\footnotetext{
${ }^{1}$ Universidade Federal de Viçosa/ Viçosa - MG, Brasil.

${ }^{3}$ Centro Universitário de Formiga/ Formiga - MG, Brasil.

Received in: 6-13-2017

Accepted in: 10-7-2017
} 
enable us to comprehend the characteristics of certain elements, along with their mobility, persistence, and interaction with the soil (Souza et al., 2011). However, it is important to highlight that the presence of inorganic and organic constituents (competitors for sorption sites) in the soil solution favors the leaching of those not retained, which should alert us to the danger of groundwater pollution (Martinez et al., 2001; Shaheen et al., 2013). Many factors influence the adsorption competition between cations in solutions, such as their hydrolysis constant, atomic mass, ionic radius, and hydrated radius (Shaheen et al., 2013). Notably, an improved adsorption could be reached under elevated valence states and reduced ionic hydrated radii (Dal Bosco et al., 2004).

In this line, Pereira et al. (2011) have stated that laboratory assays could provide us with a better understanding of influencing factors on movement and retention mechanisms of contaminants. Furthermore, lab experiments with soil columns stand out because they allow better conditions for research development, making it easier to control the variables and prevent harms to the environment. In addition, when using deformed soil samples, pore-structure homogenization could reduce the representative elementary volume in the determination of parameters for breakthrough curves (Silva et al., 2016).

Having said the above, we believe it is necessary to comprehend the dynamics of solutes in the soil in association with other ions, mainly regarding the increasing need to conduct irrigation with lower quality water sources. Thus, the present study aims to obtain the transport parameters of potassium cations within soil columns through miscible displacement of effluents. We used effluents from two different stages of a Sewage Treatment Plant (STP) and two different potassium chloride solutions with the same potassium pulse concentration found in the analyzed effluents.

\section{MATERIAL AND METHODS}

Effluent was collected from the sewage treatment plant (STP) in a limestone industry located in the centralwestern Minas Gerais states - Brazil, in the beginning of August 2016. The STP only treats effluents generated by employees. The plant can be described as compact, monoblock-type, with processes executed in glass fiber containing the following internal compartments: primary decanter, aerobic reactor, and secondary decanter.

The samples were collected after the primary decanter and at the exit pipe of the STP. They were analyzed for quality just before the use in miscible displacement experiments, as shown in Table 1. The analyzed variables were electrical conductivity and $\mathrm{pH}$ by potentiometry, biochemical oxygen demand (BOD) by iodometric titration, total nitrogen by persulfate method, total phosphorus by ascorbic method, nitrate and nitrite by N-1-naphthyl-ethylenediamine method, ammonium nitrogen by indophenol method, total iron by phenanthroline method (APHA, AWWA, WEF, 2012), turbidity by a digital turbidimeter (0.01 NTU accuracy, from 0 to $1000 \mathrm{NTU}$; emission spectrum of $880 \mathrm{~nm}$ ), potassium and sodium by flame photometry, and calcium and magnesium by atomic adsorption. Sodium adsorption ratio was calculated according to [eq. (1)].

$$
\mathrm{SAR}=\frac{\mathrm{Na}^{+}}{\sqrt{\frac{\mathrm{Ca}^{++}+\mathrm{Mg}^{++}}{2}}}
$$

In which:

SAR - sodium adsorption ratio, in $\left(\mathrm{mmol}_{\mathrm{c}} \mathrm{L}^{-1}\right)^{0.5}$;

$\mathrm{Na}^{+}$- sodium ion concentration, in $\mathrm{mmol}_{\mathrm{c}} \mathrm{L}^{-1}$;

$\mathrm{Ca}^{++}$- Calcium ion concentration, in $\mathrm{mmol}_{\mathrm{c}} \mathrm{L}^{-1}$,

$\mathrm{Mg}^{++}$- Magnesium ion concentration, in $\mathrm{mmol}_{\mathrm{c}} \mathrm{L}^{-1}$.

Potassium adsorption ratio (PAR) was estimated through [eq. (2)].

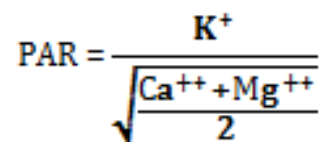

In which:

PAR - Potassium adsorption ratio, in $\left(\mathrm{mmol}_{\mathrm{c}} \mathrm{L}^{-1}\right)^{0.5}$, $\mathrm{K}^{+}$- potassium ion concentration, in $\mathrm{mmol}_{\mathrm{c}} \mathrm{L}^{-1}$.

TABLE 1. Quality parameters of effluent from two different stages of the sewage treatment plant for further characterization and preparation of $\mathrm{KCl}$ solutions.

\begin{tabular}{cccc}
\hline Parameters & Unit & Primary decanter effluent & Treated Effluent \\
\hline $\mathrm{pH}$ & - & 7.8 & 8.11 \\
E.C. & $\mathrm{dS} \mathrm{m}^{-1}$ & 1.5 & 1.5 \\
Turbidity & $\mathrm{UNT}$ & 0 & 0 \\
Potassium & $\mathrm{mg} \mathrm{L}^{-1}$ & 32 & 30 \\
Phosphorus & $\mathrm{mg} \mathrm{L}^{-1}$ & 0.63 & 1.95 \\
Total Iron & $\mathrm{mg} \mathrm{L}^{-1}$ & 0.04 & 0.07 \\
Nitrite & $\mathrm{mg} \mathrm{L}^{-1}$ & 0.01 & 0.06 \\
Nitrate & $\mathrm{mg} \mathrm{L}^{-1}$ & 0.12 & 0.5 \\
Ammoniacal-N & $\mathrm{mg} \mathrm{L}^{-1}$ & 0.98 & 0.91 \\
Nitrogen & $\mathrm{mg} \mathrm{L}^{-1}$ & 1.55 & 3.74 \\
Sodium & $\mathrm{mg} \mathrm{L}^{-1}$ & 73 & 72 \\
Calcium & $\mathrm{mg} \mathrm{L}^{-1}$ & 592 & 504 \\
Magnesium & $\mathrm{mg} \mathrm{L}^{-1}$ & 91 & 90 \\
SAR & $\left(\mathrm{mmol} \mathrm{L}_{\mathrm{c}}^{-1}\right)^{0.5}$ & 0.736 & 0.774 \\
PAR & $\left(\mathrm{mmol} \mathrm{L} \mathrm{L}^{0}\right)^{0.5}$ & 0.178 & 0.202 \\
BOD & $\mathrm{mg} \mathrm{L}^{-1}$ & 41 & 82 \\
\hline
\end{tabular}

Note: E.C.: Electrical conductivity; Ammoniacal-N: ammonium nitrogen; SAR: sodium adsorption ratio; PAR: potassium adsorption ratio; BOD: biochemical oxygen demand 
Soil deformed samples were collected at a depth range of 0.20 to $0.50 \mathrm{~m}$, from a non-cropped area in the city of Formiga - MG (Brazil), where the soil is classified as a dystrophic Red Latosol (Oxisol). In these samples, granulometric analyses were performed, being considered an average texture soil (50.8\% sand, $14.7 \%$ silt, and $34.5 \%$ clay). Table 2 shows the fertility parameters in the soil; wherein we analyzed $\mathrm{pH}$ in water; extracted potassium, calcium, and magnesium concentrations by Mehlich-1 solution; acidity by SMP extractor method; cation exchange capacity at $\mathrm{pH} 7.0$; base saturation at $\mathrm{pH} 7.0$; and organic matter content by oxidation with sodium dichromate and sulfuric acid (EMBRAPA, 1997).

TABLE 2. Fertility and organic matter analyses of soil samples (dystrophic Red Latosol) collected from B Horizon and further used in miscible displacement experiments of potassium derived from different sources.

\begin{tabular}{ccc}
\hline Parameters & Unit & Result \\
\hline $\mathrm{pH}$ in water & - & 6.30 \\
$\mathrm{P}$ & $\mathrm{mg} \mathrm{dm}^{-3}$ & 0.52 \\
$\mathrm{~K}$ & $\mathrm{mg} \mathrm{dm}^{-3}$ & 36 \\
$\mathrm{Ca}^{++}$ & $\mathrm{cmol}_{\mathrm{c}} \mathrm{dm}^{-3}$ & 1.70 \\
$\mathrm{Mg}^{++}$ & $\mathrm{cmol}_{\mathrm{c}} \mathrm{dm}^{-3}$ & 1.30 \\
$\mathrm{Al}^{+++}$ & $\mathrm{cmol}_{\mathrm{c}} \mathrm{dm}^{-3}$ & 0.00 \\
$\mathrm{H}+\mathrm{Al}$ & $\mathrm{cmol}_{\mathrm{c}} \mathrm{dm}^{-3}$ & 1.82 \\
$\mathrm{SB}$ & $\mathrm{cmol}_{\mathrm{c}} \mathrm{dm}^{-3}$ & 3.09 \\
$\mathrm{t}$ & $\mathrm{cmol}_{\mathrm{c}} \mathrm{dm}^{-3}$ & 3.09 \\
$\mathrm{~T}$ & $\mathrm{cmol}_{\mathrm{c}} \mathrm{dm}^{-3}$ & 4.91 \\
$\mathrm{~m}$ & $\mathrm{cmol}_{\mathrm{c}} \mathrm{dm}^{-3}$ & 0.00 \\
$\mathrm{~V}$ & $\mathrm{cmol}_{\mathrm{c}} \mathrm{dm}^{-3}$ & 62.03 \\
$\mathrm{OM}$ & $\mathrm{dag} \mathrm{kg}^{-1}$ & 0.9 \\
$\mathrm{~B}$ & $\mathrm{mg} \mathrm{dm}^{-3}$ & 0.1 \\
$\mathrm{Zn}$ & $\mathrm{mg} \mathrm{dm}^{-3}$ & 0.6 \\
$\mathrm{Cu}$ & $\mathrm{mg} \mathrm{dm}^{-3}$ & 0.3 \\
$\mathrm{Fe}$ & $\mathrm{mg} \mathrm{dm}^{-3}$ & 18.0 \\
$\mathrm{Mn}$ & $\mathrm{mg} \mathrm{dm}^{-3}$ & 2.7 \\
$\mathrm{~S}$ & $\mathrm{mg} \mathrm{dm}^{-3}$ & 3.1 \\
$\mathrm{RemP}$ & $\mathrm{mg} \mathrm{L}^{-1}$ & 18.3 \\
\hline
\end{tabular}

Note: $\mathrm{SB}=$ sum of the exchangeable bases $(\mathrm{Ca}+\mathrm{Mg}+\mathrm{K}) ; \mathrm{T}=$ $\mathrm{CEC}$ at $\mathrm{pH} 7.0(\mathrm{SB}+\mathrm{H}+\mathrm{Al}) ; \mathrm{V}=\mathrm{Base}$ saturation at $\mathrm{CEC}$ and $\mathrm{pH}$ $7.0(100 . \mathrm{SB} / \mathrm{T})$; OM: Oxidation with sodium dichromate + sulfuric acid; $\mathrm{t}=$ effective $\mathrm{CEC} ; \mathrm{m}=$ aluminum saturation; $\mathrm{P}, \mathrm{K}$, $\mathrm{Zn}, \mathrm{Cu}, \mathrm{Fe}, \mathrm{Mn}$ by Mehlich-I extraction; $\mathrm{Al}, \mathrm{Ca}$, and $\mathrm{Mg}$ by $\mathrm{KCl}$ extraction (l mol $\left.\mathrm{L}^{-1}\right)$; $\mathrm{H}+\mathrm{Al}$ by SMP extraction; RemP: Remaining phosphorus

Before using soil in the assays, the samples were air-dried, crushed, and then passed through a 0.002-m sieve, thus obtaining air-dried fine earth (ADFE) samples. Soil columns consisted of $20-\mathrm{cm}$ long sections of rigid PVC tube with a 4.4-cm internal diameter. All these tubes were filled uniformly and homogeneously with 180 -g soil, occupying a volume of $152 \mathrm{~cm}^{3}$ (10-cm height), which resulted in a soil density of $1,224 \mathrm{~g} \mathrm{~cm}^{-3}$.

These columns were slowly saturated by capillarity with distilled water and put on a tray. Then, they were filled with water up to about two-thirds of the column height and left rest until saturation was achieved. Afterwards, soil leaching was initiated by adding deionized water to the top of the soil columns until reaching an electrical conductivity of zero in the sample effluent.
When a steady-state flow was achieved in each experimental unit, the miscible displacement experiments began. Afterwards, the corresponding treatment solutions were put through the soil columns, using Mariotte's bottles with roller clamps along a serum hose. The treatments were named as E30 and E32 (effluent with 30 and $32 \mathrm{mg}$ $\mathrm{L}^{-1}$ of $\mathrm{K}$ ), and as $\mathrm{S} 30$ and $\mathrm{S} 32(\mathrm{KCl}$ solutions with concentrations of 30 and $32 \mathrm{mg} \mathrm{K} \mathrm{L}^{-1}$ ). The concentrations of the two latter were determined based on the $\mathrm{K}$ content found during effluent characterization.

As a safety precaution, spillways were drilled on the PVC tubes with 16-mm drains of linear low-density polyethylene (LLDPE), so the hydraulic load on the column could remain constant at $0.05 \mathrm{~m}$.

Aliquots of effluent solution were taken sequentially using 30-mL amber-glass containers. Each volume of effluent solution sampled was converted to soil pore volume, related total porosity in each column, as shown in [eq. (3)].

$$
V_{\mathrm{f}}=\frac{V_{\text {efluente }}}{\alpha \times V_{S}}
$$

In which:

$$
\begin{aligned}
& \mathrm{PV}_{\mathrm{f}}-\text { Pore volume in each container related to the } \\
& \text { referred column }\left(\mathrm{cm}^{3}\right) \text {; } \\
& \mathrm{V}_{\text {effl. }} \text { - Effluent volume collected in each container }\left(\mathrm{cm}^{3}\right) \text {; } \\
& \alpha-\text { Porosity of the soil in the column }(\%), \\
& \mathrm{V}_{\mathrm{S}}-\text { Soil volume in the column }\left(\mathrm{cm}^{3}\right) .
\end{aligned}
$$

Soil porosity in each column was determined by using [eq. (4)].

$$
\alpha=1-\frac{\rho s}{\rho p}
$$

In which:

$$
\begin{aligned}
& \rho s-\text { Soil bulk density }\left(\mathrm{g} \mathrm{cm}^{-3}\right) \\
& \rho p-\text { Particle density }\left(\mathrm{g} \mathrm{cm}^{-3}\right)
\end{aligned}
$$

Soil bulk density was calculated by [eq. (5)].

$$
\rho s=\frac{M_{s}}{V_{s}}
$$

In which:

$$
\mathrm{M}_{\mathrm{s}}-\text { Soil weight in the column }(\mathrm{g}) \text {. }
$$

After sampling, potassium concentration (C) was measured for each container using a microprocessor-based 910 digital flame photometer (Analyser, São Paulo, Brazil). It is noteworthy that sampling was conducted until the effluent relative potassium concentration $\left(\mathrm{C} \mathrm{C}_{0}^{-1}\right)$ reached one (1).

Once solute relative concentrations $\left(\begin{array}{ll}\mathrm{C} & \mathrm{C}_{0}^{-1}\end{array}\right)$ container pore volumes were gathered, the transport parameters of each treatment were defined with STANMOD software, version 2.08 (Šimůnek et al., 2008). An inverse-problem mode of the CFITIM code was used. The transport parameters determined by the software were retardation factor $(\mathrm{R})$ and Peclet number $(\mathrm{Pe})$. These 
values were then used to estimate hydrodynamic dispersion (D) and solid-water partition (kd) coefficients, by means of eqs (6) and (7), respectively.

$$
\mathrm{R}=1+\frac{\rho \mathrm{s} \times \mathrm{kd}}{\theta}
$$

In which:

$$
\begin{aligned}
& \mathrm{R} \text { - retardation factor; } \\
& \mathrm{kd} \text { - solid-water partition coefficient }\left(\mathrm{cm}^{3} \mathrm{~g}^{-1}\right), \\
& \theta-\text { soil water content }\left(\mathrm{cm}^{3} \mathrm{~cm}^{-3}\right) . \\
& \mathrm{Pe}=\frac{\mathrm{v} \times \mathrm{L}}{\mathrm{D}}
\end{aligned}
$$

In which:

$$
\begin{aligned}
& \text { Pe - Peclet number; } \\
& \mathrm{L} \text { - soil column length }(\mathrm{cm}) ; \\
& \mathrm{D} \text { - dispersion-diffusion coefficient }\left(\mathrm{cm}^{2} \mathrm{~min}^{-1}\right), \\
& \left.\mathrm{v} \text { - water speed in the pores }(\mathrm{cm} \mathrm{min})^{-1}\right) .
\end{aligned}
$$

Water and solute flow in each column was calculated using [eq. (8)].

$$
q=\frac{V_{e}}{A \times t}
$$

In which:

$\mathrm{q}$ - water flow in the soil $\left(\mathrm{cm} \mathrm{h}^{-1}\right)$;

$\mathrm{Ve}$ - collected effluent volume $\left(\mathrm{cm}^{3}\right)$;

A - cross-sectional area of the column $\left(\mathrm{cm}^{2}\right)$,

$\mathrm{t}$ - time interval used to collect the volume Ve (h).

Thus, by the relationship presented in [eq. (9)], we could obtain the actual speed of the water in the soil.

$$
v=\frac{q}{\alpha}
$$

The data were analyzed in a completely randomized design (CRD), with three replications for all treatments. Data were statistically analyzed by $\mathrm{F}$ test, and if it was significant, means were compared by the Scott-Knott's test at $5 \%$ probability. All the statistical analyses were conducted through SISVAR software, version 5.6 (Ferreira, 2014).

\section{RESULTS AND DISCUSSION}

In both treatments, $\mathrm{pH}$ was classified as basic; however, for samples after the primary decanter, it was close to neutral (7.84). After the first analysis, the results obtained for BOD, $\mathrm{P}$, and $\mathrm{N}$ showed the sewage treatment inefficiency since these elements had concentrations higher than those in the primary decanter. This result might have occurred because the effluent samples were collected from a junction box in the STP, which contains a lot of accumulated suspended solid particles. Unfortunately, we were obliged to do so since it was impossible to collect samples from the end of the system due to its construction.

As there were small variations in sodium, calcium, and magnesium concentrations, SAR values from the evaluated samples exhibited no significant differences. A correlation between electrical conductivity and RAS proved that the use of these effluents would not reduce hydraulic conductivity in the soil (Ayers \& Westcost, 1985), as confirmed during the experimental procedure. This occurs because the stability of the aggregates depends on the amount of soluble salts in the solution (measured by CE) and on the balance between $\mathrm{Ca}^{2+}$ and $\mathrm{Mg}^{2+}$ with $\mathrm{Na}^{+}$ and $\mathrm{K}^{+}$, which are represented by $\mathrm{SAR}$ and PAR, respectively. In this same line, Bourazanis et al. (2016) reported that high values of SAR associated with low ECs tend to cause clay dispersion and destruction of soil aggregates. Table 3 displays the variance analysis of the potassium transport parameters applying different solutions to the soil.

TABLE 3. ANOVA summary for potassium transport parameters in a dystrophic Red Latosol as a function of the percolation of different effluents and potassium chloride solutions.

\begin{tabular}{cccccc}
\hline Variation source & & \multicolumn{2}{c}{ MS } & $\mathrm{R}$ & $\mathrm{kd}$ \\
\cline { 3 - 6 } & $\mathrm{DF}$ & $\mathrm{Pe}$ & $\mathrm{D}$ & $89.018^{* *}$ & $13.965^{* *}$ \\
Treatment & 3 & $0.829^{\mathrm{NS}}$ & $2224.505^{\mathrm{NS}}$ & 1.475 & 0.128 \\
Error & 8 & 0.444 & 1266.673 & 10.86 & 9.56 \\
Total & 11 & & & 24.88 & 11.185 \\
CV & & 17.3 & 143.072 & 3.751 \\
Overall average & & 3.849 &
\end{tabular}

Note: $\mathrm{Pe}=$ Peclet number; $\mathrm{D}=$ Diffusion-dispersion coefficient; $\mathrm{R}=$ Retardation factor; $\mathrm{kd}=$ water-soil partition coefficient; $\mathrm{DF}=\mathrm{Degrees}$ of freedom; $\mathrm{MS}=$ Mean square; $\mathrm{NS}=$ non-significant; $* *=$ significant at $1 \%$ by the F-test $\mathrm{CV}=$ coefficient of variation.

When analyzing Table 3, one can see that there were no differences between among treatments for Peclet number (Pe) and dispersion-diffusion coefficient (D). However, different results were obtained for retardation factor $(\mathrm{R})$ and partition coefficient $(\mathrm{kd})$, confirmed by disparities among treatments for both parameters at $1 \%$ probability ( $99 \%$ trust level). This result might be due to the relationship of these parameters to the adsorption of potassium ions.

Conversely, the other parameters are related to the processes of ion transport within the soil (convection, dispersion, and diffusion). Once all columns were built to be identical physically, this should have reflected on such parameters, both in the percolation of effluents and $\mathrm{KCl}$ solutions at 30 and $32 \mathrm{mg} \mathrm{L}^{-1}$ of $\mathrm{K}$. Another factor to be 
observed is the similarity in potassium concentrations among the four treatments (E30, E32, S30, and S32) with 30 and $32 \mathrm{mg} \mathrm{L}^{-1}$, showing very close values.
Figure 1 shows the breakthrough curves of potassium for a dystrophic Red Latosol (Oxisol), according to each treatment.
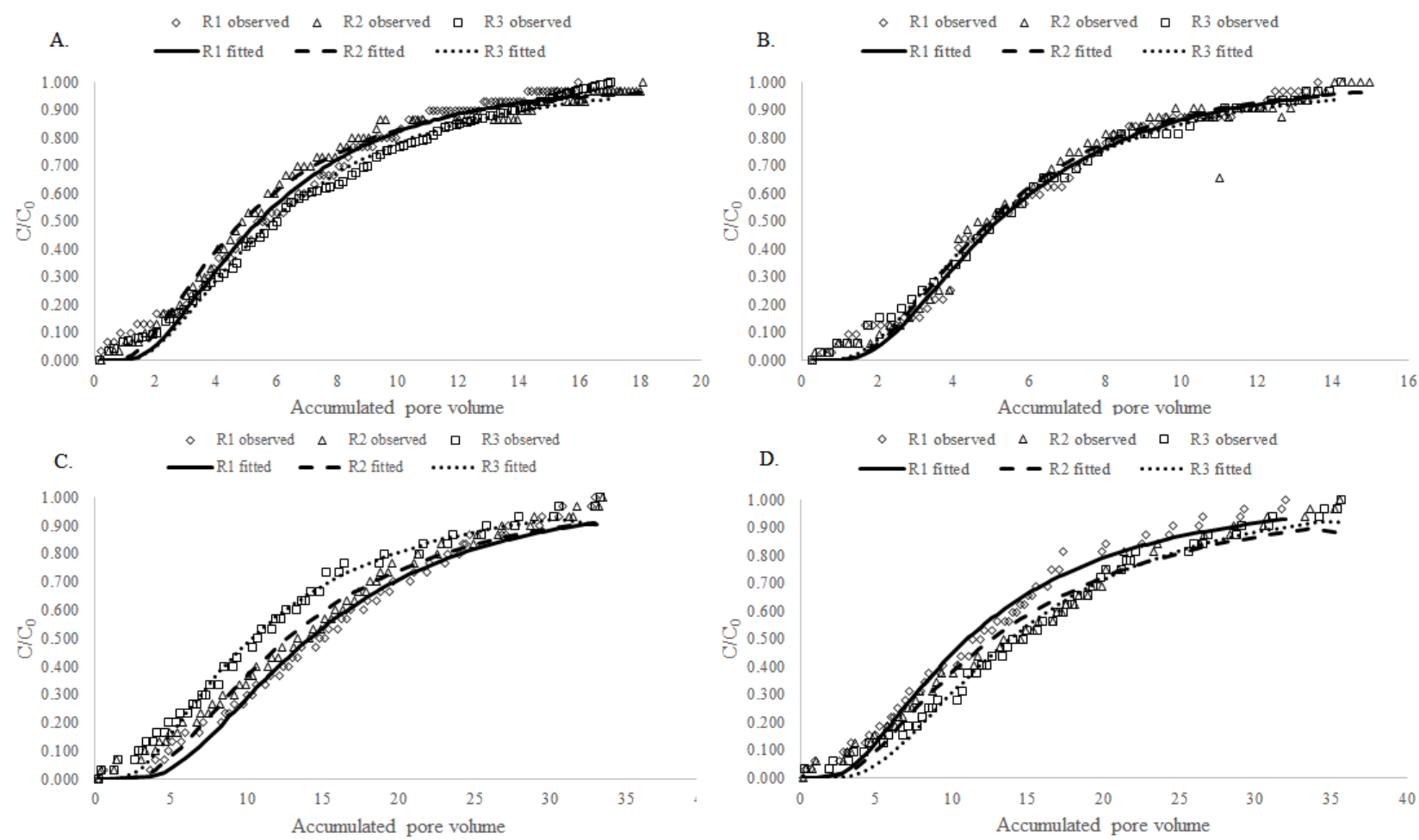

FIGURE 1. Breakthrough curves of potassium for a dystrophic Red Latosol (Oxisol) generated by effluent with $30 \mathrm{mg} \mathrm{L} \mathrm{L}^{-1}$ of $\mathrm{K}$ (A), effluent with $32 \mathrm{mg} \mathrm{L}^{-1}$ of $\mathrm{K}(\mathrm{B}), \mathrm{KCl}$ solution with $30 \mathrm{mg} \mathrm{L}^{-1}$ of $\mathrm{K}(\mathrm{C})$, and $\mathrm{KCl}$ solution with $32 \mathrm{mg} \mathrm{L}^{-1}$ of $\mathrm{K}$ (D).

Analyzing the curves in Figure 1, we observed interactions between the solutions and the solid fraction of the soil. We noted that when the pore volume (VP) at a relative concentration of 0.5 is above one, the curve shifts to the right, indicating that part of the solute would be adsorbed as solution moves down the column. The farther the pore volume from the unit at 0.5 relative concentration, the more intense the solute-soil interaction becomes. All curves obtained in this study exhibited this behavior though.
Also in Figure 1, we could notice that the pore volume required to recover potassium initial concentration was different between effluents and $\mathrm{KCl}$ solutions. In effluents, a lower number of pores were used to recover $\mathrm{K}$ pulse concentration. This means that the interaction of potassium and the soil in displacements with effluent is lower than in the case of potassium chloride solutions. Table 4 demonstrates the potassium transport parameters according to liquid with which it is applied to the soil.

TABLE 4. Transport parameters of potassium for effluent and for $\mathrm{KCl}$ solutions in soil columns of dystrophic Red Latosol (Oxisol).

\begin{tabular}{ccccc}
\hline Treatment & $\mathrm{Pe}$ & $\mathrm{D}\left(\mathrm{cm}^{2} / \mathrm{h}\right)$ & $\mathrm{R}$ & $\mathrm{kd}\left(\mathrm{cm}^{3} / \mathrm{g}\right)$ \\
\hline E30 & $3.633 \mathrm{a}$ & $131.773 \mathrm{a}$ & $6.837 \mathrm{~b}$ & $1.910 \mathrm{~b}$ \\
E32 & $4.623 \mathrm{a}$ & $112.263 \mathrm{a}$ & $6.117 \mathrm{~b}$ & $1.873 \mathrm{~b}$ \\
S30 & $6.687 \mathrm{a}$ & $152.697 \mathrm{a}$ & $15.687 \mathrm{a}$ & $5.347 \mathrm{a}$ \\
S32 & $3.453 \mathrm{a}$ & $175.553 \mathrm{a}$ & $16.100 \mathrm{a}$ & $5.873 \mathrm{a}$ \\
\hline
\end{tabular}

Note: The same letters in the columns show results with no difference by the Scott-Knott's test at $5 \%$ significance. E30: Effluent with 30 mg $\mathrm{L}^{-1}$ of $\mathrm{K}$; E32: effluent with $32 \mathrm{mg} \mathrm{L}^{-1}$ of $\mathrm{K}$; S30: $\mathrm{KCl}$ solution with $30 \mathrm{mg} \mathrm{L}^{-1}$ of $\mathrm{K}$; and S32: $\mathrm{KCl}$ solution with $32 \mathrm{mg} \mathrm{L}^{-1}$ of $\mathrm{K}$.

As previously shown by the ANOVA F-test for potassium transport parameters, $\mathrm{Pe}$ and $\mathrm{D}$ mean values were statistically equal regardless the treatment. Oliveira et al. (2013) stated that diffusive and dispersive flows are predominant to the convective, Pe between 0.01 and 50, which is in agreement with this study.

In contrast, the values obtained both for $\mathrm{R}$ and for kd were higher when using KCL solutions containing 30 and $32 \mathrm{mg} \mathrm{K} \mathrm{L}^{-1}$ if compared to the effluent values.
Distinct dispersion-diffusion coefficients are linked to varying slopes in effluent curves and, hence, to the mixing range between displacer and displaced solutions along the soil profile. This fact affects the relative concentration of an effluent solution as pore volume increases (Nielsen \& Biggar, 1962). Additionally, the results obtained in this study exhibited equal $\mathrm{D}$ values for all treatments.

Furthermore, higher kd values cause greater potassium adsorption by the soil, which results in higher $\mathrm{R}$ 
values. The presence of other cations, such as iron, sodium, calcium, and manganese in effluents jeopardizes potassium adsorption by competition for the same adsorption site.

On the other hand, the differences in potassium concentrations in displacer liquids ( 30 and $\left.32 \mathrm{mg} \mathrm{L}^{-1}\right)$ have no effect on $\mathrm{kd}$ or $\mathrm{R}$, being proved by the statistical equality ( $p<0.05$, Scott-Knott's test) of these parameters between S30 and S32 and between E30 and E32, separately (Table 4). These results can be explained by the similarity of the assessed $\mathrm{K}$ concentrations.

To evaluate potassium, calcium, and magnesium transport parameters, Matos et al. (2013) applied vinasse to different soil types and obtained $\mathrm{R}$ values of $2.17,1.27$, and 0.85 , respectively. These authors used vinasse at concentrations of $2484 \mathrm{mg} \mathrm{K} \mathrm{L}^{-1}, 1340 \mathrm{mg} \mathrm{Ca} \mathrm{L}^{-1}$, and 473 mg mg L ${ }^{-1}$; among all assessed soils, eutrophic Red (LVef) and dystrophic Red-yellow (LVad) Latosols exhibited R values of 1.43 and 1.63, respectively, indicating a greater potassium adsorption in $\mathrm{LVd}$. In this study, we encountered much higher values, being of 6.837 and 6.117 for effluents and 15.687 and 16.100 for $\mathrm{KCl}$ solutions, which contained respectively 30 and $32 \mathrm{mg} \mathrm{K} \mathrm{L}^{-1}$. This discrepancy must have been due to the low concentrations of potassium used here, besides the lower concentrations of other ions in the used effluent when compared to vinasse.

Silva et al. (2015) analyzed the influence of counter ions (calcium and ammonium) on nitrate-anion transport parameters in deformed samples of two soils (Red Nitosol and Red-yellow Latosol). Their results showed that both counter ions had no influence on nitrate mobility through the soil columns. In contrast, Martinez et al. (2001) studied the effect of cationic competition on R values and dispersion-diffusion coefficients of zinc and copper in prepared solutions. They concluded that the competition between zinc and copper reduced retention of each cation individually, which tended to reduce $\mathrm{R}$ and dispersion-diffusion coefficient. Since $\mathrm{R}$ measures the ability of a soil to retain solutes based on interactions between its liquid and solid phases during percolation (Melo et al., 2006), we observed a higher competition among ions when percolated with effluents, resulting in higher $\mathrm{R}$ for potassium if compared to $\mathrm{KCl}$ solutions with the same $\mathrm{K}$ concentrations. It is said that soil-water partition coefficient $(\mathrm{kd})$ is related to an interaction between soil and solute. When there is no interaction, $\mathrm{kd}$ is equal to zero, leading to a $\mathrm{R}$ of 1 .

When assessing an LVd soil, Ribeiro et al. (2011) inferred a decrease in $\mathrm{R}$ as the soil column length increases; they reported an $\mathrm{R}$ value of 5.86 in $10 \mathrm{~cm}$ columns for $\mathrm{KCl}$ solutions containing $130 \mathrm{mg} \mathrm{K} \mathrm{L}^{-1}$. In our study, by comparing results from $\mathrm{KCl}$ solutions of $30 \mathrm{mg}$ $\mathrm{L}^{-1}$ and $32 \mathrm{mg} \mathrm{L}^{-1}$ (Table 4), we obtained an $\mathrm{R}$ value considerably higher. These results may be associated with the $\mathrm{K}$ concentrations in solutions, i.e. the higher the ion concentrations, the quicker their sorption in the soil.

According to the same authors cited above, the $\mathrm{R}$ value in a dystrophic Red-yellow Latosol increases with the solution drainage speed, which is also in agreement with Santos et al. (2010). In this study, however, we chose to standardize the size and density of soil columns and apply the same hydraulic load to all treatments; consequently, drainage speed had no impact on our results for $\mathrm{R}$ values.

\section{CONCLUSIONS}

Among the assessed potassium transport parameters, only retardation factor $(\mathrm{R})$ and solid-water partition coefficient $(\mathrm{kd})$ presented different results for percolation of effluents and $\mathrm{KCl}$ solutions. Nevertheless, the other assessed parameters, dispersion-diffusion coefficient (D) and Peclet number (Pe), had no significant variation for either treatments. It is worth mentioning that, when applied via $\mathrm{KCl}$ solutions, potassium was more retained by the soil given its greater adsorption.

Our results highlight that potassium has a greater groundwater polluting potential if applied via effluent than with potassium chloride solution, regardless of the concentration.

\section{ACKNOWLEDGEMENTS}

The authors thank the FAPEMIG for financial support.

\section{REFERENCES}

APHA - American Public Health Association, AWWA American Water Works Association, WEF - Water Environment Federation (2012) Standard methods for the examination of water and effluent. Washington, American Public Health Association, 22ed. 1496p.

Ayers RS, Westcost DW (1985) Water quality for agriculture. Rome, FAO. 174p.

Bourazanis G, Katsileros A, Kosmas C, Kerkides P (2016). The effect of treated municipal effluent and fresh water on saturated hydraulic conductivity of a clay-loamy soil. Water Resources Management 30(8):2867-2880. DOI: http://dx.doi.org/10.1007/s11269-016-1307-9

Costa MS, Costa ZVB, Alves SMC, Ferreira Neto M, Marinho MJC (2012) Avaliação nutricional do milho cultivado com diferentes doses de efluente doméstico tratado. Irriga, 1(1):12-26. DOI:

http://dx.doi.org/10.15809/irriga.2012v1n01p12

Dal Bosco SM, Jimenez RS, Carvalho WA (2004)

Aplicação da zeólita natural escolecita na remoção de metais pesados de efluentes industriais: competição entre os cátions e processo de dessorção. Eclética Química 29(1):47-56. DOI: http://dx.doi.org/10.1590/S010046702004000100006

EMBRAPA - Centro Nacional de Pesquisa de Solos (1997) Manual de métodos de análise de solo. EMBRAPA, 2 ed. 212 p.

Ferreira DF (2014) Sisvar: a Guide for its Bootstrap procedures in multiple comparisons. Ciência e Agrotecnologia, 38(2):109-112. DOI: http://dx.doi.org/10.1590/S1413-70542014000200001 
Gonçalves MS, Sampaio SC, Suszek FL, Coelho SRM, Godoi I (2016) Atrazine leaching in soil submitted of swine effluent application. Irriga 21(1):131-139. DOI: http://dx.doi.org/10.15809/irriga.2016v21n1p131-139

Hoshino RT, Alves GAC, Barzan RR, Fregonezi GAF, Faria, RT (2016) Fertilizantes agrícolas aplicados via solução nutritiva em Cattleya labiata Lindl. Ornamental Horticulture 22(2):208-214. DOI:

http://dx.doi.org/10.14295/oh.v22i2.878

Jadoski SO, Saito LR, Prado C, Lopes EC, Sales LLSR (2010) Características da lixiviação de nitrato em áreas de agricultura intensiva. Pesquisa Aplicada \& Agrotecnologia 3(1):193-200. DOI:

http://dx.doi.org/10.5777/paet.v3i1.1008

Martinez MA, Ramos VBN, Matos AT, Oliveira, RA, Costa SN (2001) Influência da competição catiônica nos valores de fator de retardamento e coeficiente de dispersão-difusão de zinco e cobre no solo. Revista Brasileira de Engenharia Agrícola e Ambiental, 5(2):211215. DOI: http://dx.doi.org/10.1590/S141543662001000200006

Matos AT, Gariglio HAA, Lo Monaco PAV (2013) Deslocamento miscível de cátions provenientes da vinhaça em colunas de solo. Revista Brasileira de Engenharia Agrícola e Ambiental 17(7):743-749. DOI: http://dx.doi.org/10.1590/S1415-43662013000700008

Melo RF, Ferreira PA, Matos AT, Ruiz HA, Oliveira LB (2006) Deslocamento miscível de cátions básicos provenientes da água residuária de mandioca em colunas de solo. Revista Brasileira de Engenharia Agrícola e Ambiental 10(2):456-465. DOI:

http://dx.doi.org/10.1590/S1415-43662006000200029

Mendes WC, Alves Júnior J, Cunha PCR, Silva AR, Evangelista AWP, Casaroli D (2016) Potassium leaching in different soils as a function of irrigation depths. Revista Brasileira de Engenharia Agrícola e Ambiental 20(11):972-977. DOI: http://dx.doi.org/10.1590/18071929/agriambi.v20n11p972-977

Nielsen DR, Biggar JW (1962) Miscible displacement: III, Theoretical considerations. Soil Science Society of America Proceedings 26(3):216-221. DOI: http://dx.doi.org/10.2136/sssaj1962.036159950026000300 $10 \mathrm{x}$

Oliveira LFC, Nogueira JG, Frizzarim SS, Fia R, Freitas JS, Fia FRL (2013) Sorção e mobilidade do lítio em solos de áreas de disposição final de resíduos sólidos urbanos. Engenharia Sanitária e Ambiental 18(2):139-148. DOI: http://dx.doi.org/10.1590/S1413-41522013000200006

Pereira EM, Chang HK, Soto MAA (2011) Estimativa de alguns parâmetros de transporte de contaminantes para solos brasileiros. Geociências 30(3):383-398.
Pereira KTO, Oliveira FO, Cavalcante ALG, Dantas RP, Oliveira MKT, Costa JPBM (2016) Qualidade de mudas de moringa sob diferentes níveis de nutrientes aplicados via fertirrigação. Pesquisa Florestal Brasileira 26(88):497504. DOI: http://dx.doi.org/10.4336/2016.pfb.36.88.1038

Ribeiro DP, Martinez MA, Matos AT, Ruiz HA, Parreiras MSN, Cecon PR (2011) Relação da velocidade de escoamento da solução e do comprimento da coluna de solo com os parâmetros de transporte de potássio em um Latossolo e um Neossolo. Revista Brasileira de Ciência do Solo 35(6):1907-1916. DOI:

http://dx.doi.org/10.1590/S0100-06832011000600007

Santos DL, Coelho EF, Batista LS, Barros DL, Gomes Filho RR, Carvalho CM (2016) Efeito da aplicação de ureia e de cloreto de potássio por fertirrigação na vazão dos emissores e em parâmetros químicos do solo. Revista Brasileira de Agricultura Irrigada 10(5):990-998. DOI: http://dx.doi.org/10.7127/rbai.v10n500495

Santos JS, Lima VLA, Borges Júnior JCF, Silva LVBD, Azevedo CAV (2010) Mobilidade de solutos em colunas de solo com água residuária doméstica e de suinocultura. Revista Brasileira de Engenharia Agrícola e Ambiental 14(11):1226-1233. DOI: http://dx.doi.org/10.1590/S141543662010001100013

Shaheen SM, Tsadilas CD, Rinklebe J (2013) A review of the distribution coefficients of trace elements in soils: Influence of sorption system, element characteristics, and soil colloidal properties. Advances in Colloid and Interface Science 201-202:43-56. DOI:

https://doi.org/10.1016/j.cis.2013.10.005

Šimůnek J, Van Genuchten MTH, Šejna M (2008) Development and applications of the HYDRUS and STANMOD software packages and related codes. Vadose Zone Journal 7(2):587-600. DOI: https://doi.org/10.2136/vzj2007.0077

Silva LP, Miranda JH, Oliveira LA, José JV (2015) Effect of companion ion on nitrate displacement through transport parameters analysis. Engenharia Agrícola 35(1):51-62. DOI: http://dx.doi.org/10.1590/1809-4430Eng.Agric.v35n1p51-62/2015

Silva LP, De Jong Van Lier Q, Correa MM, Miranda JH, Oliveira LA (2016) Retention and Solute Transport Properties in Disturbed and Undisturbed Soil Samples. Revista Brasileira de Ciência do Solo 40:1-10. DOI: http://dx.doi.org/10.1590/18069657rbcs20151045

Souza AL, Matsura EE, Miranda JH, Colombo A (2011) Ajuste de parâmetros de transporte de solutos no solo utilizando MATLAB 6.5. Revista Engenharia Agrícola, 31(6):1064-1074. DOI: http://dx.doi.org/10.1590/S010069162011000600004 